\title{
PENGARUH BIAYA KEAGENAN, TAHAP DAUR HIDUP PERUSAHAAN, KEBIJAKAN DIVIDEN TERHADAP NILAI PERUSAHAAN DENGAN KEBIJAKAN UTANG SEBAGAI VARIABEL PEMODERASI PADA PERUSAHAAN MANUFAKTUR YANG TERDAFTAR DI BEI
}

\author{
Muhammad Yasfi \\ Kurniawan Ali Fachrudin
}

\begin{abstract}
One of the company's main objective was to enhance firm value through increased prosperity of the owners or shareholders. The separation of ownership from management in corporation creates agency problem. Managers who run companies and usually do not have stock ownership may not act in the shareholder's best interest because they maximize their own wealth.The objective of this research was to examine whether there was an effect of agency cost (dispersion of ownership and managerial ownership), firm life cycle stages, and dividend policy on firm value with debt policy as moderating variable. The population of the study is the manufacturing companies that registered in Indonesian Stock Exchange in the period of 2002-2012. Samples of 88 observations are selected using purposive sampling method. The analysis method of this research was simple regression and Moderated Regression Analysis (MRA).The result showed that dispersion of ownership and firm life cycle stages can influence firm value. The result also showed that debt policy can moderating dispersion of ownership influence firm value.
\end{abstract}

Keywords: firm value, agency cost, dispersion of ownership, managerial ownership, firm life cycle stages, dividend policy and debt policy

\section{PENDAHULUAN}

Nilai perusahaan merupakan kondisi tertentu yang telah dicapai oleh suatu perusahaan sebagai gambaran dari kepercayaan masyarakat terhadap perusahaan setelah melalui suatu proses kegiatan selama beberapa tahun, yaitu sejak perusahaan tersebut didirikan sampai dengan saat ini. Nilai perusahaan sangat penting karena dengan nilai perusahaan yang tinggi akan diikuti oleh tingginya kemakmuran pemegang saham (Gapensi, 1996) yang dikutip dari http://pustakabakul.blogspot.com. Menurut teori keagenan, pemisahan kepemilikan dan pengelolaan dapat menimbulkan konflik keagenan. Konflik keagenan menyebabkan penurunan nilai perusahaan yang akan mempengaruhi kekayaan dari pemegang saham, sehingga pemegang saham akan melakukan tindakan 
pengawasan terhadap perilaku manajemen. Kepemilikan manajerial kemudian dipandang sebagai mekanisme kontrol yang tepat untuk mengurangi konflik tersebut.

Apabila manajer mempunyai kepemilikan saham dalam perusahaan, manajer tersebut tentu tidak menginginkan perusahaan tersebut bangkrut. Sehingga manajer tersebut akan berusaha meningkatkan kinerja dan sekaligus meningkatkan nilai perusahaan, karena dengan meningkatnya nilai perusahaan maka nilai kekayaannya sebagai pemegang saham akan meningkat pula.

Penelitian Hardoyo (2013) menyatakan bahwa kepemilikan manajerial berpengaruh terhadap nilai perusahaan. Namun pada penelitian Permanasari (2010) menyatakan bahwa kepemilikan manajerial tidak berpengaruh terhadap nilai perusahaan. Hal ini dikarenakan perusahaan yang diteliliti memiliki persentase kepemilikan manajerial yang rendah. Tahap daur hidup perusahaan dapat mempengaruhi nilai perusahaan. Perusahaan yang berada pada tahapan pertumbuhan akan memiliki prospek ke depan yang lebih baik, sehingga diharapkan mempengaruhi pergerakan nilai perusahaan. Sedangkan perusahaan pada tahapan dewasa cenderung mengalami perkembangan yang terbatas sehingga nilai sahamnya lebih stabil.

Kebijakan dividen merupakan salah satu aspek penting dalam tujuan memaksimalkan nilai perusahaan. Apabila perusahaan memutuskan untuk membagi laba yang diperoleh sebagai dividen, berarti akan mengurangi jumlah laba ditahan yang akhirnya mengurangi sumber dana internal yang digunakan untuk mengembangkan perusahaan. Tetapi dengan membagikan dividen pun, perusahaan dapat mengurangi biaya keagenan dikarenakan mengurangi jumlah arus kas perusahaan yang seringkali digunakan oleh manajer untuk digunakan secara boros (tidak efisien).

Penelitian Wongso (2012) menyatakan bahwa kebijakan dividen yang diproksikan dengan variabel dividend payout ratio (DPR) berpengaruh terhadap nilai perusahaan. Namun pada penelitian Mardiyati et al. (2012) menyatakan bahwa kebijakan dividen yang diproksikan dengan variabel DPR tidak berpengaruh terhadap nilai perusahaan. Hal ini sesuai dengan teori yang dikemukakan oleh 
Modigliani dan Miller yang menyatakan bahwa kebijakan dividen tidak mempengaruhi nilai perusahaan. Karena rasio pembayaran dividen hanyalah rincian, dan tidak mempengaruhi kesejahteraan pemegang saham.

Kebijakan utang juga dapat dihubungkan dengan nilai perusahaan. Kebijakan utang merupakan kebijakan perusahaan tentang seberapa jauh sebuah perusahaan menggunakan pendanaan utang. utang dapat digunakan untuk mengendalikan penggunaaan free cash flow secara berlebihan oleh pihak manajemen. Sehingga mengurangi investasi yang sia-sia, dengan demikian akan meningkatkan nilai perusahaan.

Berdasarkan uraian maka penulis tertarik untuk meneliti pengaruh biaya keagenan, tahap daur hidup perusahaan, dan kebijakan dividen terhadap nilai perusahaan dengan kebijakan utang sebagai variabel pemoderasi. Penelitian ini akan mengambil sampel pada perusahaan manufaktur di BEI selama perioda tahun 2002-2012.

\section{TINJAUAN PUSTAKA}

\section{Nilai Perusahaan}

Nilai perusahaan dalam penelitian ini menggunakan price to book value, seperti halnya penelitian yang pernah dilakukan Endraswati (2008). Price to book value yang tinggi akan membuat pasar percaya pada prospek perusahaan pada masa yang akan datang. Kondisi ini akan mendorong pada peningkatan harga saham perusahaan. Nilai perusahaan yang tinggi mencerminkan kemakmuran pemegang saham yang tinggi pula, hal ini sesuai dengan keinginan pemilik perusahaan. Tetapi apabila harga saham terlalu tinggi, itu juga akan berdampak buruk bagi perusahan dikarenakan saham menjadi tidak likuid di pasaran. Karena itu harga saham dijaga supaya tidak terlalu tinggi dan juga tidak terlalu rendah.

\section{Teori Keagenan}

Hubungan keagenan ada ketika salah satu pihak (prinsipal) menyewa pihak lain (agen) untuk melaksanakan suatu jasa dan dalam melakukan hal itu mendelegasikan wewenang untuk membuat keputusan kepada agen tersebut (Anthony dan Vijay, 2005: 269). Pemegang saham menyewa CEO dan 
mengharapkan ia untuk bertindak bagi kepentingan mereka.

Teori keagenan mengasumsikan semua individu bertindak untuk kepentingan mereka sendiri. Agen diasumsikan akan menerima kepuasan tidak hanya dari kompensasi keuangan tetapi juga dari tambahan yang terlibat dalam hubungan suatu keagenan, seperti waktu luang yang banyak, kondisi kerja yang menarik, keanggotaan klub, dan jam kerja yang fleksibel. Biaya keagenan dapat diproksikan dengan 2 variabel, yaitu:

\section{a. Dispersion of Ownership}

Dispersion of ownership adalah jumlah sebaran kepemilikan saham dari seluruh saham yang beredar dari suatu perusahaan. Yang dimaksud dengan jumlah sebaran kepemilikan adalah jumlah kelompok-kelompok pemilik saham dari suatu perusahaan atas keseluruhan saham yang beredar. Jumlah kelompok pemegang saham dianggap sebagai wakil dari dispersion of ownership (Mollah, 2000).

b. Kepemilikan Manajerial

Berdasarkan teori keagenan, perbedaan kepentingan antara manajer dan pemegang saham ini mengakibatkan timbulnya konflik yang biasa disebut agency conflict. Konflik kepentingan yang sangat potensial ini menyebabkan pentingnya suatu mekanisme yang diterapkan guna melindungi kepentingan pemegang saham (Jensen dan Meckling, 1976 dalam Permanasari, 2010).

\section{Tahap Daur Hidup Perusahaan}

Teori product life cycle beranggapan bahwa produk (industri) akan mengalami evolusi melalui beberapa fase, yaitu fase perkenalan, fase pertumbuhan, fase kematangan, dan fase penurunan. Titik-titik fase atau tahap siklus hidup tersebut ditentukan dari dua hal, yaitu volume penjualan dan laba rugi perusahaan dan tiap fase evolusi akan berpengaruh terhadap strategi kompetisi dan kinerja perusahaan (Porter dan Grant, 1995 dalam Atmini, 2002).

Pada tahap start-up, perusahaan belum memperoleh banyak pendapatan tetapi banyak mengeluarkan kas untuk pengembangan produk, pengembangan pasar, dan ekspansi kapasitas. Tahap growth, pangsa pasar dan pendapatan perusahaan mulai meningkat. Sedangkan pada tahap mature, pangsa pasar semakin 
kuat. Oleh karena itu, pada dua tahap siklus hidup ini mencerminkan kondisi ekonomi perusahaan yang baik.

\section{Kebijakan Dividen}

Salah satu kebijakan yang harus diambil oleh manajemen adalah memutuskan apakah laba yang diperoleh oleh perusahaan selama satu perioda akan dibagi semua atau dibagi sebagian untuk dividen dan sebagian lagi tidak dibagi dalam bentuk laba ditahan. Kebijakan dividen sering dianggap sebagai sinyal bagi investor dalam menilai baik buruknya perusahaan, hal ini disebabkan karena kebijakan dividen dapat membawa pengaruh terhadap harga saham perusahaan. Menurut Mardiyati et al., (2012) terdapat beberapa pandangan mengenai pengaruh kebijakan dividen terhadap nilai perusahaan:
a. Kebijakan Dividen Tidak Relevan
b. Kebijakan Dividen Yang Relevan
c. Efek informasi (Information Content, or Signaling Hypothesis)
d. Clientele Effect

\section{Kebijakan Utang}

utang adalah instrumen yang sangat sensitif terhadap perubahan nilai perusahaan. Semakin tinggi proporsi utang maka semakin tinggi harga saham, namun pada titik tertentu peningkatan utang akan menurunkan nilai perusahaan karena manfaat yang diperoleh dari penggunaan utang lebih kecil daripada biaya yang ditimbulkannya (Soliha dan Taswan, 2002).

\section{Pengaruh Dispersion of Ownership terhadap Nilai Perusahaan}

Menurut Mollah (2000) dalam Djumahir (2008) jumlah kelompok pemegang saham dianggap sebagai wakil dari dispersion of ownership. Penelitian Hardoyo (2013) menunjukkan dispersion of ownership berpengaruh terhadap nilai perusahaan. Hal ini menunjukkan bahwa jumlah kelompok pemilik saham dari suatu perusahaan atas suatu keseluruhan saham dapat mempengaruhi nilai suatu perusahaan. Sesuai dengan teori keagenan, pemegang saham yang semakin menyebar akan mengakibatkan kesulitan dalam proses monitoring perusahaan sehingga akan menimbulkan masalah keagenan. Berdasar teori dan hasil penelitian 
terdahulu, maka hipotesis yang diajukan dalam penelitian ini adalah:

$\mathrm{H}_{\mathrm{a} 1}$ : Dispersion of ownership berpengaruh terhadap nilai perusahaan.

\section{Pengaruh Kepemilikan Manajerial terhadap Nilai Perusahaan}

Seorang manajer yang sekaligus menjadi pemegang saham pada perusahaan tersebut tidak akan menginginkan perusahaan tersebut bangkrut sehingga manajer tersebut akan meningkatkan kinerja dan sekaligus meningkatkan nilai perusahaan. Hasil penelitian Hardoyo (2013) menyatakan bahwa kepemilikan manajerial berpengaruh terhadap nilai perusahaan. Berdasar teori dan hasil penelitian terdahulu, maka hipotesis yang diajukan dalam penelitian ini adalah:

$\mathrm{H}_{\mathrm{a} 2}$ : Kepemilikan manajerial berpengaruh terhadap nilai perusahaan.

\section{Pengaruh Tahap Daur Hidup Perusahaan terhadap Nilai Perusahaan}

Pengukuran tahap daur hidup perusahaan dapat dilakukan dengan proksi proporsi laba ditahan terhadap total ekuitas (Murhadi dan Liliana, 2011). Tahap daur hidup perusahaan dapat mempengaruhi nilai perusahaan. Perusahaan yang berada pada tahapan pertumbuhan akan memiliki prospek ke depan yang lebih baik sehingga diharapkan mempengaruhi pergerakan nilai perusahaan. Sedangkan perusahaan pada tahapan dewasa cenderung mengalami perkembangan yang terbatas sehingga nilai sahamnya lebih stabil. Berdasar teori dan hasil penelitian terdahulu, maka hipotesis yang diajukan dalam penelitian ini adalah:

$\mathrm{H}_{\mathrm{a} 3}$ : Tahap daur hidup perusahaan berpengaruh terhadap nilai perusahaan

\section{Pengaruh Kebijakan Dividen terhadap Nilai Perusahaan}

Kebijakan dividen dapat diukur dengan menggunakan dividen payout ratio (DPR) Menurut Mollah (2000) dalam Djumahir (2008), DPR adalah perbandingan antara jumlah dividen yang dibagikan dalam setiap lembar saham pada akhir tahun dalam satuan persen. Pembayaran dividen kepada pemegang saham dapat mengurangi sumber-sumber dana yang dikendalikan oleh manajer, sehingga mengurangi kekuasaan manajer. Berdasar teori yang dijabarkan, maka hipotesis yang diajukan dalam penelitian ini adalah:

$\mathrm{H}_{\mathrm{a} 4}$ : Kebijakan dividen berpengaruh terhadap nilai perusahaan. 


\section{Interaksi antara Dispersion of Ownership dengan Kebijakan Utang}

Teori yang dikemukakan oleh Jensen dan Meckling (1976) dalam Ariemorti (2003) menyatakan bahwa jika jumlah kelompok pemegang saham semakin menyebar, maka konsentrasi kepemilikan saham akan terpecah dalam persentase yang kecil. Hal ini menyebabkan kekuatan para pemegang saham untuk mengontrol tindakan manajer menjadi rendah. Perusahaan perlu meningkatkan utang guna mendisiplinkan tindakan manajer dalam perusahaan. Berdasar teori yang dijabarkan, maka hipotesis yang diajukan dalam penelitian ini adalah:

$\mathrm{H}_{\mathrm{a} 5}$ : Kebijakan utang berpengaruh terhadap hubungan antara dispersion of ownership dan nilai perusahaan.

\section{Interaksi antara Kepemilikan Manajerial dengan Kebijakan Utang}

Menurut Gusti (2013) utang yang besar dengan risiko yang besar akan membuat manajer berpikir ulang untuk menggunakan utang dalam jumlah yang banyak. Bila semakin tinggi persentase kepemilikan saham yang dimiliki oleh manajer dalam perusahaan akan menambah kehati-hatian manajer dalam mengambil keputusan pendanaan. Dengan demikian, diharapkan dapat menurunkan kebijakan atas utang yang digunakan untuk mendanai kegiatan perusahaan dan risiko kebangkrutan dapat diminimalkan. Berdasar teori yang dijabarkan, maka hipotesis yang diajukan dalam penelitian ini adalah:

$\mathrm{H}_{\mathrm{a} 6}$ : Kebijakan utang berpengaruh terhadap hubungan antara kepemilikan manajerial dan nilai perusahaan.

\section{Interaksi antara Tahap Daur Hidup Perusahaan dengan Kebijakan Utang}

Keputusan apakah modal dipenuhi dari sumber internal atau eksternal merupakan suatu keputusan yang tidak mudah. Penggunaan sumber eksternal tidak menjadi masalah selama perusahaan mengalami pertumbuhan. Perusahaan mempunyai harapan memperoleh laba dan arus kas yang cukup tinggi untuk menutupi kewajiban terhadap pemilik modal. Namun tidak demikian dengan perusahaan yang tidak mengalami pertumbuhan, penggunaan sumber eksternal akan menambah beban dalam bentuk kewajiban membayar bunga dan turunnya nilai perusahaan. Berdasar teori yang dijabarkan, maka hipotesis yang diajukan 
dalam penelitian ini adalah:

$\mathrm{H}_{\mathrm{a}}$ : Kebijakan utang berpengaruh terhadap hubungan antara tahap daur hidup perusahaan dan nilai perusahaan.

\section{Interaksi antara Kebijakan Dividen dengan Kebijakan Utang}

Ketika perusahaan menggunakan dana yang ada untuk membiayai operasional dan tidak membagikan kepada pemilik saham, maka perusahaan kemungkinan tidak akan menggunakan pendanaan melalui utang. Demikian juga sebaliknya ketika dana yang ada justru dibagikan sebagai dividen, maka perusahaan akan cenderung melakukan pendanaan melalui utang.

$\mathrm{H}_{\mathrm{a} 8}$ : Kebijakan utang berpengaruh terhadap hubungan antara kebijakan dividen dan nilai perusahaan.

\section{METODA PENELITIAN}

\section{Populasi, Pengambilan Sampel, dan Sampel}

Populasi yang digunakan dalam penelitian ini adalah perusahaan yang terdaftar di BEI pada tahun 2002-2012. Pemilihan sampel menggunakan purposive sampling, yaitu berdasar kriteria yang disajikan pada tabel 1. Jumlah sampel yang memenuhi kriteria pada tabel di atas adalah 8 perusahaan dengan pengamatan kinerja keuangan selama 11 tahun, sehingga total data sebanyak 88 data.

Tabel 1

Penggunaan Metoda Purposive Sampling

\begin{tabular}{|l|c|}
\hline \multicolumn{1}{|c|}{ Kriteria Perusahaan } & Jumlah \\
\hline $\begin{array}{l}\text { Perusahaan manufaktur yang terdaftar di BEI untuk tahun } \\
\text { 2002-2012 }\end{array}$ & 136 perusahaan \\
\hline $\begin{array}{l}\text { Perusahaan manufaktur yang tidak memiliki data } \\
\text { kepemilikan manajerial selama 8 tahun dalam perioda 2002- } \\
2012\end{array}$ & (114 perusahaan) \\
\hline $\begin{array}{l}\text { Perusahaan manufaktur yang tidak memiliki data kebijakan } \\
\text { dividen selama 5 tahun dalam perioda 2002-2012 }\end{array}$ & (14 Perusahaan) \\
\hline $\begin{array}{l}\text { Perusahaan manufaktur yang memiliki data kepemilikan } \\
\text { manajerial selama 8 tahun serta memiliki kebijakan dividen } \\
\text { selama 5 tahun dalam perioda 2002-2012 }\end{array}$ & 8 Perusahaan \\
\hline
\end{tabular}

Sumber: Data sekunder, diolah (2013) 


\section{Definisi Operasional dan Pengukuran Variabel}

\section{a. Nilai Perusahaan (Y)}

Variabel dependen dalam penelitian ini adalah nilai perusahaan. Nilai perusahaan menggunakan price to book value seperti dalam penelitian Endraswati (2008). Price to book value dihitung dengan membagi harga saham dengan nilai buku. Nilai buku dihasilkan dari ekuitas dibagi rata-rata jumlah saham yang beredar.

\section{b. Dispersion of Ownership ( $\left.\mathrm{X}_{1}\right)$}

Dispersion of ownership adalah jumlah sebaran kepemilikan saham dari seluruh saham yang beredar dari suatu perusahaan. Pengertian jumlah sebaran kepemilikan adalah jumlah kelompok-kelompok pemilik saham dari suatu perusahaan atas keseluruhan saham yang beredar. Jumlah kelompok pemegang saham dianggap sebagai wakil dari dispersion of ownership (Mollah, 2000) dalam Djumahir (2008). Dispersion of ownership dapat dihitung dengan rumus sebagai berikut:

DISPER-OWN = jumlah kelompok pemegang saham

\section{c. Kepemilikan Manajerial ( $\left.\mathbf{X}_{2}\right)$}

Kepemilikan manajerial adalah kepemilikan saham oleh manajemen perusahaan yang diukur dengan persentase jumlah saham yang dimiliki oleh manajemen Sujono dan Soebiantoro (2007) dalam Sabrina (2010) yang kutip pada laman http://pustakabakul.blogspot.com. Kepemilikan manajerial dapat diukur dengan persentase saham yang dimiliki manajemen dalam perusahaan tersebut.

\section{d. Tahap Daur Hidup Perusahaan $\left(\mathbf{X}_{3}\right)$}

Tahap daur hidup perusahaan adalah tahapan perusahaan mulai dari tahap pertumbuhan sampai matang. Pengukuran tahapan daur hidup perusahaan dilakukan dengan proksi proporsi laba ditahan terhadap total ekuitas (Murhadi dan Liliana, 2011).

\section{e. Kebijakan Dividen ( $\left.\mathbf{X}_{4}\right)$}

Proksi dari kebijakan dividen yang dipilih untuk penelitian ini adalah dividend payout ratio (DPR). Menurut Mardiyati et al., (2012) DPR lebih dapat menggambarkan perilaku oportunistik manajerial yaitu dengan melihat berapa 
besar keuntungan yang dibagikan kepada shareholders sebagai dividen dan berapa yang disimpan di perusahaan. DPR merupakan perbandingan antara dividen per lembar saham terhadap laba per lembar saham.

\section{f. Kebijakan Utang ( $\left.\mathbf{X}_{5}\right)$}

Proksi dari kebijakan utang pada penelitian ini adalah debt to equity ratio (DER). Tujuan dari rasio ini adalah untuk mengukur kemampuan perusahaan dalam membayar utang-utang yang dimilikinya dengan modal atau ekuitas yang ada. DER merupakan perbandingan antara total utang terhadap total modal.

\section{Teknik Analisis Data}

\section{Analisis Deskriptif}

Statistik deskriptif berkaitan dengan penerapan metoda statistik untuk mengumpulkan, mengolah, menyajikan, dan menganalisis data kuantitatif secara deskriptif. Statistik deskriptif memberikan gambaran suatu data yang dilihat dari nilai mean, deviasi standar, varian, maksimum, dan minimum (Ghozali, 2011: 19).

\section{Analisis Model Regresi Data Panel}

Penelitian ini menggunakan data panel karena merupakan kombinasi dua jenis data lain yaitu runtut waktu (time series) dan data silang tempat (crosssection). Time series yaitu kumpulan observasi terhadap nilai-nilai sebuah variabel dari beberapa perioda. Sedangkan cross-section adalah data yang terdiri atas satu atau lebih variabel yang dikumpulkan dalam satu perioda yang sama (Gujarati dan Porter, 2012:28). Teori ekonometrika menyatakan bahwa untuk mengestimasi parameter model dengan data panel terdapat tiga metoda yang dapat digunakan (Sinaga, 2013), yaitu:

\section{a. Common Effects}

Metoda ini merupakan pendekatan paling sederhana dalam pengolahan data panel dengan mengombinasikan data time series dengan cross section tanpa melihat perbedaan waktu dan individu. Metoda ini mengasumsikan bahwa koefisien regresi memiliki nilai yang sama untuk setiap cross section sehingga tidak ada cross section yang lebih baik dibandingkan yang lainnya. 


\section{b. Metoda Efek Tetap (Fixed Effects)}

Metoda common effects terdapat kesulitan terbesar yaitu asumsi intercept dan slope dari persamaan regresi yang dianggap konstan. Metoda ini mengasumsikan bahwa perbedaan antara individu dapat diakomodasi melalui intersep yang berbeda. Namun perbedaaan intersep terjadi hanya antara individu sedangkan intersep antar waktu adalah konstan (time invariant). Generalisasi umum yang dilakukan dalam metoda efek tetap ini adalah dengan memasukkan dummy variable.

\section{c. Metoda Efek Random (Random Effects)}

Penambahan dummy variable pada metoda efek tetap dapat menimbulkan trade off yaitu mengurangi derajat kebebasan (degree of freedom) yang pada akhirnya mengurangi efisiensi parameter yang diestimasi. Parameter-parameter yang berbeda antar individu maupun antar waktu dimasukkan ke dalam error. Berdasar alasan ini, maka intersep tidak dianggap tetap tetapi sebagai nilai rata-rata ditambah dengan error. Karena inilah, metoda efek acak sering juga disebut model komponen error (error component model).

Winarno (2009) yang dikutip dari laman www.dukuntansi.wordpress.com mengemukakan secara ringkas menentukan langkah data panel dengan Eviews sebagai berikut:

\section{a. Estimasi dengan Fixed Effects}

Estimasi ini dilakukan dengan melakukan uji Chow (Common Vs Fixed effect). Uji Chow digunakan untuk memilih model yang akan digunakan antara model estimasi common effects atau model estimasi fixed effects. Uji ini menggunakan distribusi statistik chi square, bila nilai $\mathrm{F}$ hitung lebih besar daripada nilai $\mathrm{F}$ tabel maka model yang digunakan adalah model estimasi fixed effects, sebaliknya bila nilai $\mathrm{F}$ hitung lebih kecil daripada nilai $\mathrm{F}$ tabel maka model yang digunakan adalah model estimasi common effects (Widarjono, 2009) dalam http://egienews.blogspot.com.

\section{b. Estimasi dengan Random Effects}

Estimasi ini dilakukan dengan melakukan uji Haussman (Random vs Fixed). Jika $\mathrm{H}_{\mathrm{o}}$ diterima, maka gunakan model random effects. Namun jika $\mathrm{H}_{\mathrm{o}}$ ditolak maka gunakan model fixed effects. 


\section{Uji Moderated Regression Analysis (MRA)}

Menurut Ghozali (2011: 225) untuk menguji hubungan antara variabel independen terhadap variabel dependen dapat menggunakan model persamaan regresi sederhana. Sedangkan untuk menguji pengaruh dari variabel pemoderasi menggunakan dua prosedur, yaitu subgroup analysis dan moderated regression analysis (MRA). Subgroup analysis digunakan untuk mengidentifikasi ada tidaknya jenis moderator Homologizer. Subgroup analysis diuji dengan menggunakan alat analisis Chow Test. Chow Test adalah alat untuk menguji test for equality of coefficients atau uji kesamaan koefisien (Ghozali, 2011: 167).

Jika nilai $\mathrm{F}$ hitung > F tabel, maka menolak hipotesis nol dan dapat disimpulkan bahwa debt equity ratio dapat memoderasi pengaruh dispersion of ownership, kepemilikan manajerial, tahap daur hidup perusahaan dan dividend payout ratio terhadap nilai perusahaan. Sharma et al. (1981) dalam Ghozali (2011: 224) mengelompokkan variabel pemoderasi menjadi tiga kelompok seperti terlihat pada tabel berikut:

Tabel 2

Jenis-jenis Variabel Pemoderasi

\begin{tabular}{|l|l|l|}
\hline & $\begin{array}{c}|c| \\
\text { Berhubungan dengan } \\
\text { kriterion dan atau prediktor }\end{array}$ & $\begin{array}{l}\text { Tidak berhubungan dengan } \\
\text { kriterion dan prediktor }\end{array}$ \\
\hline $\begin{array}{l}\text { Tidak berinteraksi } \\
\text { dengan predictor }\end{array}$ & $\begin{array}{l}\text { Intervening, Exogen, } \\
\text { Antesedent, predictor }\end{array}$ & Moderator (Homologizer) \\
\hline $\begin{array}{l}\text { Berinteraksi dengan } \\
\text { Predictor }\end{array}$ & Moderator (Quasi Moderator) & Moderator (Pure Moderator) \\
\hline
\end{tabular}

Sumber: Ghozali (2011)

Menurut Ghozali (2011: 229) untuk menggunakan MRA dengan satu variabel prediktor, maka kita harus membandingkan tiga persamaan regresi untuk menentukan jenis variabel pemoderasi. Ketiga persamaan tersebut adalah:

$\mathrm{Y}=\beta_{0}+\beta_{1} \mathrm{X}+\mathrm{e}_{\mathrm{it}}$

$Y=\beta_{0}+\beta_{1} X+\beta_{2} Z+e_{i t}$

$Y=\beta_{0}+\beta_{1} \quad X+\beta_{2} \quad Z+\beta_{3} X * Z+e_{i t}$ 
1. Bila persamaan (2) $\beta_{2} Z$ memiliki nilai yang signifikan dan persamaan (3) $\beta_{3}$ $\mathrm{X}^{* \mathrm{Z}}$ tidak signifikan, maka variabel $\mathrm{Z}$ bukan variabel pemoderasi, tapi merupakan suatu variabel independen, intervening, exogenous, antecedent atau variabel dependen.

2. Bila persamaan (2) $\beta_{2} \mathrm{Z}$ memiliki nilai yang tidak signifikan dan persamaan (3) $\beta_{3} X^{*} \mathrm{Z}$ signifikan, maka variabel $\mathrm{Z}$ merupakan variabel pemoderasi murni.

3. Bila persamaan (2) $\beta_{2} \mathrm{Z}$ memiliki nilai yang tidak signifikan dan persamaan (3) $\beta_{3} X^{*} \mathrm{Z}$ tidak signifikan, maka variabel $\mathrm{Z}$ merupakan variabel homologizer moderator.

4. Bila persamaan (2) $\beta_{2} Z$ memiliki nilai yang signifikan dan persamaan (3) $\beta_{3}$ $\mathrm{X} * \mathrm{Z}$ signifikan, maka variabel $\mathrm{Z}$ merupakan variabel kuasi moderator.

\section{PEMBAHASAN}

\section{Analisis Deskriptif}

Tabel 3

Statistik Deskriptif Sektor Manufaktur Perioda 2002-2012

\begin{tabular}{|c|c|c|c|c|c|c|}
\hline & PBV & DISP & KM & TDHP & DPR & DER \\
\hline Mean & 0.882159 & 6.670455 & 8.310568 & 0.526737 & 23.57045 & 0.792727 \\
\hline Median & 0.690000 & 6.000000 & 1.760000 & 0.511821 & 24.09000 & 0.405000 \\
\hline Maximum & 4.860000 & 17.00000 & 25.61000 & 1.000000 & 122.7700 & 10.17000 \\
\hline Minimum & 0.100000 & 2.000000 & 0.000000 & 0.005754 & -20.86000 & 0.040000 \\
\hline Std. Dev. & 0.794334 & 3.153985 & 10.06342 & 0.266930 & 23.85567 & 1.226725 \\
\hline
\end{tabular}

Sumber: Data Sekunder, diolah (2013)

Nilai price book value menunjukkan rata-rata pada sektor manufaktur sebesar 0,882159 dan nilai deviasi standar sebesar 0,7494334. Nilai maksimum dari variabel price book value sebesar 4,86. Nilai minimum variabel price book value sebesar 0,1 . 


\section{Pemilihan Model Regresi}

\section{Tabel 4}

Hasil Uji Model dengan Menggunakan Likelihood Ratio Test

\begin{tabular}{|c|c|c|c|}
\hline Effects Test & Statistic & d.f. & Prob. \\
\hline Cross-section F & 6.832375 & $(7,71)$ & 0.0000 \\
\hline Cross-section Chi-square & 45.318736 & 7 & 0.0000 \\
\hline
\end{tabular}

Sumber: Data sekunder, diolah (2013)

Tabel 4 menunjukkan bahwa nilai probability pada cross-section Chi-square memperlihatkan angka 0,000 dengan tingkat signifikansi 95\% $(\alpha=5 \%)$ yang berarti menolak $\mathrm{H}_{\mathrm{o}}$, sehingga model regresi yang digunakan dalam penelitian ini adalah fixed effects. Perhitungan tersebut juga menunjukkan bahwa nilai $\mathrm{F}$ hitung lebih besar daripada $\mathrm{F}$ tabel, yaitu 8,2 > 0,304, sehingga keputusan yang diambil adalah menolak $\mathrm{H}_{\mathrm{o}}$. Hasil menunjukkan bahwa model regresi yang sebaiknya digunakan adalah model fixed effects.

\section{Pembahasan Hasil Hipotesis}

Hasil pengujian $\mathrm{H}_{\mathrm{a} 1}$ menunjukkan hasil bahwa dispersion of ownership berpengaruh terhadap nilai perusahaan dan hubungan antara dispersion of ownership terhadap nilai perusahaan adalah negatif. Hasil pengujian terhadap $\mathrm{H}_{\mathrm{a}}$ dalam penelitian ini konsisten dengan penelitian Hardoyo (2013). Hal tersebut berarti penurunan dispersion of ownership akan meningkatkan nilai perusahaan. Hubungan negatif ini dapat disebabkan karena semakin sedikit jumlah kelompok pemilik saham maka akan semakin sedikit juga kepentingan pihak-pihak yang berbenturan, sehingga akan mengurangi konflik yang mungkin akan terjadi dalam perusahaan. Oleh karena itu, tentu akan membuat proses monitoring terhadap perusahaan lebih terkonsentrasi. Proses monitoring yang lebih terkonsentrasi membuat kinerja perusahaan semakin meningkat. Hal ini tentu saja akan meningkatkan kesejahteraan perusahaan, sehingga akan meningkatkan nilai perusahaan.

Hasil pengujian hipotesis terhadap $\mathrm{H}_{\mathrm{a} 2}$ menunjukkan hasil bahwa kepemilikan manajerial tidak berpengaruh terhadap nilai perusahaan. Hasil penelitian ini bertolak belakang dengan penelitian Endraswati (2008) namun 
konsisten dengan penelitian Permanasari (2010). Hal ini dikarenakan kepemilikan manajerial pada perusahaan manufaktur di Indonesia cenderung masih rendah, yang dapat dilihat dari statistik deskriptifnya yaitu rata-rata kepemilikan manajerial sebesar 8,310568. Rendahnya persentase saham yang dimiliki oleh manajemen mengakibatkan pihak manajemen belum merasa ikut memiliki perusahaan karena tidak semua keuntungan dapat dinikmati oleh manajemen yang menyebabkan pihak manajemen termotivasi untuk memaksimalkan utilitasnya sehingga merugikan pemegang saham. Selain itu dengan rendahnya kepemilikan saham oleh manajemen membuat kinerja manajemen juga cenderung rendah sehingga tidak mempengaruhi nilai perusahaan.

Hasil pengujian $\mathrm{H}_{\mathrm{a} 3}$ menunjukkan hasil bahwa tahap daur hidup perusahaan berpengaruh terhadap nilai perusahaan dan hubungan antara tahap daur hidup perusahaan terhadap nilai perusahaan adalah positif. Hal tersebut berarti semakin tinggi tahap daur hidup perusahaan semakin tinggi juga nilai perusahaannya. Menurut Murhadi dan Liliana (2011) perusahaan dengan RETE yang rendah cenderung berada pada tahapan growth, sedangkan perusahaan dengan RETE yang tinggi cenderung pada tahapan mature.

Tabel 5

Kriteria Tahap Daur Hidup Perusahaan

\begin{tabular}{|c|c|c|}
\hline & Growth & Mature \\
\hline \multirow{2}{*}{ RETE } & $0-0,49$ & $0,5-1$ \\
\hline
\end{tabular}

Sumber: Murhadi dan Liliana (2011), diolah (2014)

Penelitian ini menunjukkan nilai rata-rata RETE perusahaan 0,526737 . Hal ini berarti perusahaan yang diteliti termasuk pada tahapan mature. Perusahaan pada tahapan mature cenderung dipercaya oleh pangsa pasar. Oleh karena itu, pada tahapan ini perusahaan memperoleh sejumlah pendanaan sehingga mampu menghasilkan laba positif yang mencerminkan kondisi ekonomi perusahaan yang baik. Hal ini tentu akan meningkatkan nilai perusahaan.

Hasil pengujian hipotesis $\mathrm{H}_{\mathrm{a} 4}$ menunjukkan bahwa kebijakan dividen yang diproksikan DPR tidak berpengaruh terhadap nilai perusahaan. Hasil penelitian ini 
konsisten dengan Mardiyati et al., (2012) dan sesuai dengan teori yang dikemukakan oleh Modigliani dan Miller dalam Mardiyati et al. (2012) bahwa kebijakan dividen tidak mempengaruhi nilai perusahaan. Karena rasio pembayaran dividen hanyalah rincian dan tidak mempengaruhi kesejahteraan pemegang saham. Meningkatnya nilai dividen tidak selalu diikuti dengan meningkatnya nilai perusahaan.

Hasil pengujian terhadap $\mathrm{H}_{\mathrm{a} 5}$ menunjukkan bahwa kebijakan utang berpengaruh terhadap hubungan antara dispersion of ownership dengan nilai perusahaan sebagai variabel pemoderasi murni. Hasil ini menunjukkan bahwa jumlah kelompok pemegang saham yang semakin menyebar dapat menyebabkan konsentrasi kepemilikan saham terpecah dalam persentase yang kecil. Kekuatan pemegang saham untuk mengontrol tindakan manajer menjadi rendah sehingga pihak manajemen dengan leluasa menggunakan free cash flow secara berlebihan yang cenderung akan diinvestasikan melebihi tingkat yang optimum dan sering digunakan untuk konsumsi secara berlebihan yang tidak ada kaitannya dengan kegiatan utama perusahaan, sehingga hal tersebut dapat menurunkan nilai perusahaan. Karena itu diperlukan kebijakan utang untuk mengendalikan penggunaan free cash flow tersebut.

$\mathrm{H}_{\mathrm{a}}$ merupakan pengujian interaksi antara variabel independen yaitu kepemilikan manajerial dengan variabel kebijakan utang sebagai variabel pemoderasi. Syarat utama untuk melakukan pengujian moderasi adalah adanya pengaruh dari variabel independen yaitu kepemilikan manajerial terhadap variabel dependen yaitu nilai perusahaan.

Hasil pengujian terhadap $\mathrm{H}_{\mathrm{a}}$ menunjukkan bahwa kebijakan utang tidak berpengaruh terhadap hubungan antara tahap daur hidup perusahaan dengan nilai perusahaan bukan variabel moderator, tetapi merupakan variabel homologizer moderator. Variabel homologizer moderator mempengaruhi kekuatan hubungan tetapi tidak berinteraksi dengan variabel independen dan tidak berhubungan baik dengan variabel independen maupun variabel dependen (Ghozali, 2011). Kuatnya hubungan tahap daur hidup perusahaan dan nilai perusahaan tergantung dari ukuran besarnya nilai error term. 
Hasil pengujian $\mathrm{H}_{a 8}$ menunjukkan hasil bahwa kebijakan utang tidak berpengaruh terhadap hubungan antara kebijakan dividen dan nilai perusahaan. Ha8 merupakan pengujian interaksi antara kebijakan dividen sebagai variabel independen dengan variabel pemoderasi yaitu kebijakan utang. Syarat utama untuk melakukan pengujian moderasi adalah adanya pengaruh dari variabel independen yaitu kebijakan dividen terhadap variabel dependen.

\section{SIMPULAN, KETERBATASAN, DAN SARAN}

Berdasar hasil pengujian hipotesis yang telah dilakukan, maka dapat diambil simpulan bahwa variabel dispersion of ownership dan tahap daur hidup perusahaan berpengaruh terhadap nilai perusahaan. Sementara itu, Variabel kepemilikan manajerial dan kebijakan dividen tidak berpengaruh terhadap nilai perusahaan. Dengan demikian penelitian ini menolak $\mathrm{H}_{\mathrm{a} 2}$ dan $\mathrm{H}_{\mathrm{a} 6}$.

Penelitian ini masih banyak kekurangan yang perlu disempurnakan. Hal ini dikarenakan masih terdapat beberapa keterbatasan sebagai berikut:

1. Sulitnya mendapatkan data untuk variabel kepemilikan manajerial dan kebijakan dividen. Hal ini dikarenakan tidak semua perusahaan manufaktur di BEI memiliki data kepemilikan manajerial dan melakukan pembagian dividen.

2. Penelitian ini hanya menggunakan 8 sampel perusahaan yang sesuai dengan kriteria pemilihan sampel.

Berdasar hasil penelitian yang telah dilakukan, saran yang dapat diajukan untuk penelitian selanjutnya adalah sebagai berikut:

1. Peneliti selanjutnya diharapkan mempertimbangkan pengambilan sampel yang luas, baik dari segi waktu pengamatan, kriteria maupun sektor-sektor industri yang diamati. Karena dengan tidak terfokus pada satu jenis perusahaan atau industri, diharapkan dapat memperoleh koefisien yang mencerminkan reaksi pasar modal secara keseluruhan.

2. Nilai adjusted $\mathrm{R}^{2}$ persamaan regresi pada penelitian ini adalah sebesar $55 \%$, yang menunjukkan bahwa kemampuan persamaan regresi ini untuk menjelaskan besarnya variasi yang terjadi dalam variabel dependen adalah sebesar 55\%. Sehingga untuk penelitian selanjutnya diharapkan menambah 
variabel independen lain yang dimungkinkan berpengaruh terhadap nilai perusahaan seperti seperti variabel kinerja keuangan perusahaan dan ukuran perusahaan sehingga hasil penelitian menjadi lebih baik dan akurat.

\section{DAFTAR PUSTAKA}

Anthony, Robert N dan Vijay Govindarajan. 2005. Management Control System. Jakarta: Salemba Empat.

Atmini, Sari. 2002. Asosiasi Siklus Hidup Perusahaan dengan Incremental ValueRelevance Informasi Laba dan Arus Kas. Jurnal Riset Akuntansi Indonesia. Volume 5 No. 3, September 2002. Hal. 257-276.

Ariemorti, Yunita P. 2003. Pengaruh Struktur Kepemilikan terhadap Kebijakan Utang pada Perusahaan Manufaktur yang Go Public di Bursa Efek Jakarta Perioda Tahun 1998- 2000 [Online]. Didapatkan: http://eprints.undip.ac.id [29 September 2013].

Damodaran. 2001. Sumber Modal pada Setiap Siklus Hidup Perusahaan [Online]. Didapatkan: http//blog.stie-mce.ac.id [29 September 2013].

Djumahir. 2008. Pengaruh Biaya Agensi, Tahap Daur Hidup Perusahaan, dan Regulasi terhadap Kebijakan Dividen pada Perusahaan Manufaktur di Bursa Efek Indonesia. Jurnal Manajemen dan Kewirausahaan. Volume 11 No. 2, September 2012. Hal. 144- 153.

Endraswati, Hikmah. 2008. Pengaruh Struktur Kepemilikan dan Kebijakan Dividen terhadap Nilai Perusahaan dengan Kebijakan Utang sebagai Variabel Moderating pada Perusahaan di BEI [Online]. Didapatkan: http://eprints.stainsalatiga.ac.id [27>September2013].

Gapensi, Bringham. 1996. Nilai Perusahaan [Online]. Didapatkan: http://pustakabakul.blogspot.com [26September 2013].

Ghozali, Imam. 2011. Aplikasi Analisis Multivariate dengan Program SPSS. Semarang: Penerbit Universitas Diponegoro.

Gujarati, Damodar N dan Dawn C. Porter. 2012. Dasar-dasar Ekonometrika. Buku 1 Edisi 5. Jakarta: Salemba Empat. 
Gusti, Bertha Firyanni. 2013. Pengaruh Free Cash Flow dan Struktur Kepemilikan Saham terhadap Kebijakan Utang dengan Investment Opportunity Set sebagai Variabel Moderating [Online]. Didapatkan: http://ejournal.unp.ac.id [5 Januari 2014].

Hardoyo, Hangguyah. 2013. Analisis Pengaruh Agency Cost dan Corporate Social Responsibility (CSR) terhadap Nilai Perusahaan Manufaktur dan Pertambangan yang Terdaftar di BEI Tahun 2007-2011 [Online]. Didapatkan: http://repository.upnyk.ac.id [27 September 2013]

Indahningrum, Rizka P dan Ratih Handayani. 2009. "Pengaruh Biaya Agensi, Tahap Daur Hidup Perusahaan, dan Regulasi terhadap Kebijakan Dividen pada Perusahaan Manufaktur di Bursa Efek Indonesia”. Jurnal Bisnis dan Akuntansi. Volume 11 No. 3, Desember 2009. Hal. 189-207.

Kusumadilaga, Rimba. 2010. Pengaruh Corporate Social Responsibility terhadap Nilai Perusahaan dengan Profitabilitas sebagai Variabel Moderating. Skripsi. Semarang: Universitas Diponegoro.

Laila, Noor. 2011. Analisis Pengaruh Good Corporate Governance terhadap Nilai Perusahaan. Skripsi. Semarang: Universitas Diponegoro.

Lestari. 2001. Analisis Faktor-faktor yang Berpengaruh terhadap Kebijakan Utang Perusahaan Manfaktur di BEJ dalam Konteks Agency Theory (1997-1999) [Online]. Didapatkan: http://eprints.undip.ac.id [5 Januari 2014].

Mardiyati, Umi, Gatot Nazir A, dan Ria Putri. 2012. Pengaruh Kebijakan Dividen, Kebijakan Utang dan Profitabilitas terhadap Nilai Perusahaan Manufaktur yang Terdaftar di Bursa Efek Indonesia (BEI) Perioda 2005-2010. Jurnal Riset Manajemen Sains Indonesia. Volume 3 No. 1, 2012.

Murhadi, Werner R dan Liliana Inggrit Wijaya. 2011. "Studi Pengaruh Good Corporate Governance, Analyst Coverage, dan Tahapan Daur Hidup terhadap Kebijakan Deviden”. Jurnal Manajemen dan Bisnis. Volume 10 No. 1, Maret 2011. Hal. 111-126.

Pasadena, Rizka Persia. 2013. Pengaruh Likuiditas, Leverage, Profitabilitas dan Ukuran Perusahaan terhadap Kebijakan Dividen pada Perusahaan Manufaktur yang Terdaftar di Bursa Efek Indonesia. Skripsi. Jakarta: Universitas Islam Negeri Syarif Hidayatullah.

Permanasari, Wien Ika. 2010. Pengaruh Kepemilikan Manajemen, Kepemilikan 
Institusional, dan Corporate Social Responsibility terhadap Nilai Perusahaan. Skripsi. Semarang: Universitas Diponegoro.

Priyatno, Dwi. 2008. Uji Hipotesis Menggunakan Regresi Berganda, Uji F, Uji t, dan Adjusted $R$ Squared, 2013, [Online]. Didapatkan: http//dataolah.blogspot.com [ 2 September 2013].

Sabrina. 2010. Teori Kepemilikan Perusahaan dan Pengertian Kepemilikan Perusaaan[Online]. Didapatkan: http://pustakabakul.blogspot.com [26 September 2013].

Sinaga, Tintien J. 2013. Pengaruh Kebijakan Utang terhadap Nilai Perusahaan dengan Tingkat Kesehatan Keuangan dan Free Cash Flow sebagai Variabel Moderasi. Skripsi. Depok: Universitas Indonesia.

Soliha, Euis dan Taswan. 2002. Pengaruh Kebijakan Utang terhadap Nilai Perusahaan serta Beberapa Faktor yang Mempengaruhinya [Online]. Didapatkan: http://id-jurnal.blogspot.com [5 Januari 2014].

Sutrisno. 2009. Manajemen Keuangan Teori, Konsep dan Aplikasi. Yogyakarta: Ekonisia.

Widarjono. 2009. Part 3: Uji Chow (Pemilihan Regresi Data Panel) [Online]. Didapatkan: http://egienews.blogspot.com [20 November 2013].

Winarno. 2009. Menentukan Langkah Data Panel dengan EVIEWS [Online]. Didapatkan: <http//dukuntansi.wordpress.com [2 September 2013].

Wongso, Amanda. 2012. Pengaruh Kebijakan Dividen, Struktur Kepemilikan, dan Kebijakan Utang terhadap Nilai Perusahaan dalam Perspektif Teori Agensi dan Teori Signaling. Jurnal Ilmiah Mahasiswa Manajemen Unika Widya Mandala Surabaya. Volume 1 No. 5, 2012 